\title{
The Work of the Vietnamese Fatherland Front Towards the Grassroots Level Today
}

\author{
Dinh Van Chi \\ Faculty of Party Building, Ho Chi Minh City Cadre Academy, Ho Chi Minh City, Vietnam \\ Email address: \\ dinhvanchi84@gmail.com
}

To cite this article:

Dinh Van Chi. The Work of the Vietnamese Fatherland Front Towards the Grassroots Level Today. International Journal of Philosophy. Vol. 9, No. 1, 2021, pp. 72-77. doi: 10.11648/j.ijp.20210901.17

Received: March 5, 2021; Accepted: March 22, 2021; Published: March 30, 2021

\begin{abstract}
This study aims to find out the theory and practice of the Vietnamese Fatherland Front's activities at the grassroots level. For this purpose, the study is based on 3 basic hypotheses: 1/ What is the Vietnamese Fatherland Front? 2/What is the origin and view of the role, position, function, and modes of operation of this organization? $3 /$ How effective are the Vietnamese Fatherland Front's activities at the grassroots? From the objectives and hypotheses to the research, the author has used scientific research methods such as analysis and synthesis, interpretation and induction, abstraction and generalization, logic, history, and comparison to find out results and give recommendations to the work of the Vietnamese Fatherland Front at the grassroots level. The study has found out that the Vietnamese Fatherland Front at grassroots level has carried out well the task of uniting the people, promoting and improving the quality of the people's lives. The study has suggested that to work effectively, the Vietnamese Fatherland Front needs to understand the local situation. It also needs to mobilize all classes including ethnic minorities, intellectuals, businesspeople, religious people, overseas Vietnamese, ethnic minority groups, etc. It should also implement the campaign "All People Unite to Build a Cultural Life in Residential Areas".
\end{abstract}

Keywords: Work, Vietnamese Fatherland Front, Grassroots Level

\section{Introduction}

The revolution is the cause of the people, by the people, and for the people. To have a successful revolution, there must be a force that is strong enough to defeat all the enemies and build a new society successfully. It is critical to bring into full play the patriotism of the entire nation, practice solidarity of all classes, peoples, religions, social classes widely since solidarity is an invincible force [1].

President Ho Chi Minh and our Party determined the right way for the Vietnamese revolution, clearly pointing to national independence and socialism as the only way to liberate the nation, regain independence for the country, and freedom, happiness for the people [2]. At the same time, we also found a way to unite the whole nation into a powerful force to successfully carry out that task.

The Vietnamese Fatherland Front is a political alliance, a voluntary union of socio-political organizations, and typical individuals of social classes, ethnic groups, religions and the Vietnamese abroad [3]. Political coalition is to connect sociopolitical forces into a unified bloc to achieve a common political goal of gaining and holding the government, using it to protect the homeland and the results of the revolution, developing economy, and bringing a prosperous and happy life for the people. The identification of the Fatherland Front as a political coalition organization correctly reflected its nature. To fit with the revolutionary mission in each period, it is necessary to set out the correct common goal to expand the unity and gather revolutionary forces in the Front. In the current period, the 9th National Congress of the Party has clearly stated: "It is necessary to realize the modern unity of nations, religions, classes, classes, economic sectors, all sexes, all ages and regions of the land. country, members of the Party and non-Party members, working people and retired people, all members of the great Vietnamese family whether living in Vietnam or abroad". "Taking the goal of maintaining independence, unity, for the rich people, strong country, fair society, democracy and civilization as similar points; showing respect for different opinions, not contrary to the common interests of the nation; eliminating prejudice and discrimination about the past, class, and composition; building an open and trusting spirit each other, looking to the 
future" [4]. All-people solidarity bloc in the Vietnamese Fatherland Front has always been strengthened and developed based on a solid working-class alliance with the peasant class and the contingent of intellectuals [5].

In this study the author aimed to find out the theory and practice of the Vietnamese Fatherland Front's activities at the grassroots level and its contributions to the success of Vietnamese revolution at different periods.

\section{Literature Review}

On November 18, 1930, the Central Standing Committee of the Communist Party of Vietnam issued a directive to establish the Allied Anti-Imperialist Association - the first organizational form of the Unified National Front to gather all patriotic forces to conduct the revolution to liberate the nation [6]. During the past 90 years, the Vietnamese Fatherland Front has always made great contributions to the history of the Vietnamese revolution.

Over the periods of the revolution, with different forms and names, the National Front for the Unity of Vietnam was constantly growing and maturing, making great contributions to the great victory of the people. After the liberation of the South, our country followed the path of socialism, the Vietnam Fatherland Front became a part of the political system, an inevitable part of socialist democracy.

The Vietnamese Fatherland Front has been a part of the political system that includes the Party, the State, the Vietnamese Fatherland Front, and mass organizations. This regulation stems from the practical and objective requirements of the revolutionary cause. It comes from the political institution: our country is a democratic one, all power belongs to the people. This is also a historical and traditional issue since the Party created the Front, the Party is both a member and leader of the Front. After gaining the government, the Party, the government, and the Front are the constituent parts of the political system. Although the roles, positions, functions, and modes of operation of these organizations differ, they all have methods to exercise and promote people's ownership and have a common goal of striving to build building a peaceful, independent, unified, democratic, rich, and strong Vietnam country with a worthy position in the international arena. "The Fatherland Front is the political basis of the people's administration", which defines more clearly the position of the Fatherland Front in the political system. The Vietnamese Fatherland Front plays a very important role in gathering and building the great unity bloc of the entire people, promoting the people's mastery, implementing democratic consultation, coordinating and unifying actions between members in the cause of building and defending the Socialist Vietnam [7]. Building the great unity bloc of the entire people, promoting the unity of the whole nation is the responsibility of the Party, the State, all levels, branches, and the whole political system, of which the Vietnamese Fatherland Front plays an important role.

The role of the Vietnamese Fatherland Front is not confirmed by the Front itself but recognized by the people and history. The glorious victory of the August Revolution in 1945 was associated with the cause of the Viet Minh Front. After the August Revolution, the people's democratic government and the socialist political system were born. The Unified National Front became an indispensable member of our country's political system. The Front's role continued to be affirmed in political life. Ho Chi Minh affirmed: "The Front's policy is a very important one. Front's work was a very important one in the whole revolutionary work. In the people's democratic revolution as well as in the socialist revolution, the Unified National Front is still one of the great forces of the Vietnamese revolution [8].

The achievement of the Viet Minh Front was the continuation of the pre-prepared revolutionary cause of the Allied Anti-Imperialist Association (1930-1936) and the Indochina Democratic Front (1936-1939). The Viet Minh Front was followed by the Lien Viet Front that contributed to the victory of the resistance war against French colonialism. Following the Lien Viet Front, the Vietnamese Fatherland Front was born, gathering the people to conduct the socialist revolution in the North, supporting the unification of the country. During the war against the US to save the country, the Vietnamese Fatherland Front together with the National Front for the Liberation of South Vietnam and the Vietnam Union of National Forces, Democracy and Peace united the people of the country, fulfilling the glorious historical mission: liberating the South, defending the North, completing the people's democratic revolution in the whole country. Since the reunification of the country, the Vietnamese Fatherland Front has played an important role in consolidating and strengthening the block of great unity for the entire people to build and defend the Socialist Vietnam Fatherland.

The national construction platform in the period of transition to socialism (Supplement and development in 2011) determined: "The Vietnamese Fatherland Front and mass organizations play a very important role in the cause of great solidarity for the entire people to build and defend the country. They represented and protected the legitimate rights and interests of the people, taking care of the interests of union members, practicing democracy and building a healthy society, participating in building the Party and State, educating revolutionary ideals and ethics, civic rights and obligations, and strengthening the relationship between the people and the Party and State.

In the four-level system of the Front, the Fatherland Front of communes, wards, and towns (hereinafter referred to as the Grassroots Fatherland Front) has an important position and is a gathering place of people regardless of class, ethnicity, religion, profession, etc.; the place where everyday life is associated with the daily life of each person; where directly implementing the Party's policies, policies, State laws, and the Front's action plan. The grassroots level is associated with the close interests of all classes of the people, a measure of the effectiveness of the Front's work. The revolutions come from the grassroots level; the people unite first and foremost from the grassroots level. 
In the residential areas of communes, wards, and towns, the process of socio-economic renewal has been taking place and is playing an increasingly important role in the process of renovation. The impacts of the socialist-oriented market economy, the rich and poor differentiation, the process of democratization of social life, and revolutionary tasks in the new era are posing new requirements for the organization and activities of the Front at the grassroots level, requiring the Front to renew itself, striving to fulfill assigned roles, functions, and tasks, contributing to the renewal and improvement of the quality of the political system in communes, wards, and towns. The Fatherland Front in communes, wards, and towns needs to be strengthened and expanded in terms of organization and practical activities to gather the people. It is the place where demonstrates the will and aspirations of strata of the people, where actions are unified among members, participating with the government in resolving conflicts within the people, implementing democracy and social renewal; caring for and protecting the legitimate interests of all classes of people; building supervision and government protection, participating in social management, performing economic, cultural, social, security and defense tasks, building grassroots political systems, contributing to strengthen the close relationship between the people, the Party and the State [9].

\section{Results and Discussion}

\subsection{Understanding the Local Situation}

Objects of the Front staff to mobilize are the households and each citizen. Therefore, if we want to deploy and well perform the work, the Front must understand and grasp the local situation with the elements as follows:

Total land area, total cultivated land area, the total number of households, total number of the people, occupations of the locality, average food, income, number of policy households, number of rich and wealthy poverty, households with people suffering from social evils, etc. the local strengths and limitations, characteristics affecting local traffic hubs, businesses, schools, and bordering areas [10]

The number of party members, union members, the strengths and weaknesses of the Party cell, branches and unions of party members, and union members.

\subsection{Mobilize Ethnic Minorities}

Promoting the role of the Fatherland Front and mass organizations, the Fatherland Front and mass organizations have regular and close coordination with state agencies, forces, and organizations in the locality to organize more activities on the grassroots level, especially in ethnic minority areas, remote and extremely difficult areas. To mobilize farmers to eradicate hunger and reduce poverty, get rich justly and legally. Closely connect to understand people's thoughts and aspirations, promoting and replicating positive initiatives, typical collectives, and individuals in the ethnic community, etc.
Building strong Fronts and unions, attracting more people to join unions, ensuring practical and effective operations, meeting the practical benefits of union members, and preventing ethnic minorities from illegal acts.

Promoting the role of reputable people in the community of ethnic groups. Reputable people in the community can be commune officials, village patriarch, village head, priest, etc. Village elders are the elders in the village, in the lineages, and among the ethnic groups in the village. They are often exemplary people, knowledgeable about village affairs, customs, and rituals of the lineages and their people or ethnic groups not living in the village; have the ability and experience to handle harmoniously and effectively work, kinship relations, and ethnic groups. They are respected and revered as "village elders" naturally, on a voluntary principle. From the actual activities, it shows that the village patriarch's role is emphasized mainly from their understanding and exemplarity, by their ability and experience to harmoniously handle village affairs, and law, the lineage, and ethnicity; they know how to persuade and encourage, tell the people, make the people believe, and follow. This is the "bridge" between the Party, the State, socio-political organizations with the people, making many things resolved "rationally reasonable".

In the current period, the priest still plays a certain role in ethnic life. They are the spiritual supporters of the village, who play an important role in common community ceremonies and many other family rituals. At great ceremonies, the priest transmits the community's aspirations to the deity to bless villagers healthy, with good rain, good wind, and lush crops. Also, the priest is considered a "healer" and "folk artist" of the people. Thus, from a certain angle, the priest has contributed to preserving the national cultural heritage. However, superstitious activities, taking advantage of profits by some priests must be handled satisfactorily.

\subsection{Mobilize Intellectuals, Businesspeople, and Overseas Vietnamese}

Intellectuals are the main force in industrialization and modernization, and an important intellectual resource of the Party and State. Investment in building the contingent of intellectuals is investment for the development. Practice democracy, respect, and promote freedom of thought in intellectual activities. Create an environment and favorable conditions for intellectuals to function. Appreciate intellectuals based on properly assessing the quality, capacity, and results of dedication; adopting a special policy for talented people and leading experts. Consolidating, developing, and renewing the contents and modes of operation of member organizations of the Vietnam Union of Science and Technology Associations and the Vietnam Union of Literature and Art Associations from central to grassroots levels. Creating a healthy environment to promote the creative capacity and improve the moral qualities of intellectuals. Consolidate intellectual associations by improving professionalism, professional performance and social services, political awareness, and professional ethics 
for members of member organizations, especially young members. Study and establish suitable types of intellectual associations according to the provisions of the law to attract and encourage scientific and technological intellectuals of overseas Vietnamese, especially those with a high level of expertise to participate in building the country. Promote education on political ideas to help scientific and technological intellectuals to deeply realize their responsibility towards the country. Amend, supplement and promulgate legal documents, mechanisms, and policies related to intellectual associations from the central to grassroots level to ensure a favorable environment to promote the creativity of intellectuals in the industrial construction and national defense. Continue to institutionalize, amend, and promulgate legal documents related to intellectual associations and strengthen the Party's leadership over intellectual associations [11].

Build a strong team of businessmen with national spirit, political enlightenment, business culture, high social responsibility, qualified to lead and manage operating enterprises with equality, efficiency, high competitiveness, and strong bond, etc. To mobilize the team of entrepreneurs effectively, first of all, it is necessary to raise awareness of officials, party members, and the people about the position and role of the business circle in industrialization, modernization, and international integration. Create an equal and favorable business and production environment for businessmen in socio-economic development. Uphold the ethics, business culture, social responsibility, the national spirit of the business team, build stable and harmonious labor relations, and strengthen the bond between businessmen and employees. Promote the role of the representative organizations of the business community and business teams such as the Vietnam Chamber of Commerce and Industry, business associations, business teams, and employers in Vietnam. Strengthen the Party's leadership in building and promoting the role of the team of business people. Focus on Party development, building party organizations in enterprises of all economic sectors. Renovate the Party's leadership content and methods for organizations and unions in enterprises [12].

\subsection{Mobilize Religious People}

Firstly, mobilize religious dignitaries. Many of them are highly educated, have a deep understanding of religious doctrines, laws, and rituals. Therefore, this is a force that plays an important role in religious activities and has a great influence on the masses of believers. Currently, religious dignitaries in our country are increasing in quantity, quality and strongly modernizing from the improvement of theological and doctrinal level to the general educational level. Most of them have the national spirit, agreeing with the "good life and good faith" lifestyle, operating in the direction of progressive practice, and wish to have normal religious activities within the framework of the law. It can be said that mobilizing the masses of believers is a delicate work for each specific person. Especially for people with prestige and position in the churches (dignitaries), the problem becomes more necessary, sensitive, and complex. Therefore, in practice, when conducting mass mobilization, it is necessary to combine flexibly in many forms including propaganda, education, persuasion; to take advantage of religious dignitaries and monks; gather in patriotic emulation movements; coordinate with the mass organizations, the Fatherland Front in mass mobilization work; through different relationships that mobilize the priest on many sides: from the church, from the superior of the dignitaries; from the state management that encourages remind; from the masses, believers expressed sympathy, support, and encouragement for dignitaries in good deeds; from relatives, reputable people in the community doing particular work, exchange, persuade, remind, encourage.

Second, mobilize religious followers

According to the Ordinance on Beliefs, religion "believers are people who believe in a religion and are recognized by religious organizations". Religious people have their characteristics, so to mobilize people with religion to use special methods, it is necessary to combine the following methods: concentrated movement and particular movement; economic method, educational method, persuasion, appropriate administrative method, according to the following basic principles:

When dealing with dignitaries and religious believers, they should avoid arguing about theory and theology. Do not propaganda about "scientific atheism" in religious institutions and struggle with religious ideas. This is an issue that needs to be clearly defined to avoid misunderstanding about the Party's religious policy. Consistent policies of the Party and State are always respecting and guaranteeing the right to freedom of belief, religion, and freedom of non-belief and religion. All discrimination is strictly forbidden based on beliefs or religions; resolutely oppose the abuse of religion for non-religious political purposes. Respect believers' religious beliefs, avoid offending their religious feelings. It is necessary to have a certain understanding of the doctrines, and rituals of each religion; master the undertakings and policies of the Party and State on religion to have appropriate mobilization methods. Dignitaries and religious believers must be part of the general campaign of the entire people, for rich people, strong country, democracy, justice, civilization

\subsection{Implement the Campaign "All People Unite to Build a Cultural Life in Residential Areas"}

Firstly, form a Steering Committee of the campaign "All people unite to build a cultural life in residential areas" at commune, ward, and town levels, which may include the following components [13]:

The secretary of the party committee or the president of the people's committee or the chairman of the Fatherland front committee of the commune, ward, or town is the head of the steering committee.

Chairman or vice-chairman of the commune Fatherland Front committee: the head or deputy head of the Social and Cultural Committee of the commune, ward, town People's 
Committee is the deputy head of the Steering Committee.

Members of the Steering Committee are heads of people's unions, heads of departments and branches, and heads of mass mobilization boards in villages and hamlets.

The decision to establish the Steering Committee shall be made by the Party Committee of the People's Committee or the Fatherland Front Committee of the commune, ward, or town (the head of the campaign steering committee at any organization is decided by that organization).

The campaign steering committee has a plan to deploy, direct the entire campaign in each period of 6 months and 1 year; assign each member of the steering committee to follow the campaign area according to the campaign plan in their communes, wards, and towns; organize preliminary and final review of the campaign.

Secondly, form a campaign committee "All people unite to build a cultural life in hamlets, villages..." which may include the following components:

The Party cell secretary or the Head of the Front's working committee is the head of the campaigning committee.

The head or deputy head of the Front's working committee or the head of the village, hamlet, etc., is the deputy head of the campaigning committee.

Members of the campaigning committee include heads of people's unions at villages, hamlets, villages, etc.

The decision to establish a campaign committee signed by the Steering Committee of the campaign at commune and ward level at the request of the head of the campaigning committee of a village, hamlet, etc. The head or deputy head of the Front's working committee or the head of the village, hamlet, etc., is the deputy head of the campaigning committee.

Thirdly, the campaigning committee "All people unite to build a cultural life in villages, hamlets..." is responsible for the following tasks:

Organize the arrangement of population groups (selfgoverning groups) according to residential areas in the village, hamlet, etc. Each self-governing group of people can have from 20 households or more depending on the characteristics of each village. The self-governing people's group has a group leader and deputy leader appointed by the household members.

The rural and hamlet campaigning committee thoroughly learns the purpose, meaning and content of the campaign to each population group.

Make suggestions for residential groups to register their plans and targets for the campaign. The village and hamlet mobilization committee organizes a registration ceremony to emulate the campaign for population groups. The village and hamlet mass mobilization committee instructs the residential groups to register the implementation of the "cultural family" according to the standards. Monthly, quarterly meetings of the village mobilization committee, hamlet, etc. with population group leaders to learn from experience in implementing campaign plans in their units to regularly promote the campaign [14].

The campaign "All people unite to build a cultural life in residential areas" took place long-term in the renovation period, so the district and provincial committees of Vietnam Fatherland Front should apply according to specific conditions. In each residential area, to build the target content, avoid the imposition of targets, and strive to perform the content in the direction that the following year is higher than the previous year so that the campaign could go into people's lives.

\section{Conclusion}

The study has found out that the Vietnamese Fatherland Front at grassroots level, mass organizations have carried out well the task of uniting people by various forms, promoting and improving the quality of activities of People's unions, socio-professional organizations, social organizations, strive to fulfill the tasks of socio-economic development in the locality and throughout the country; coordinating with State agencies to work more on the grassroots level, to each household, especially in remote and extremely difficult areas; mobilize and help people eliminate poverty, get rich legally, implement the democratic regulations at the grassroots level, protect the legitimate interests of the people, build selfgoverning communities in villages, hamlets, and residential groups, specifically:

1) The study shows that the Vietnamese Fatherland Front is a political alliance, a self-reliant union of political organizations and socio-political organizations

2) The study has pointed out the origin of the Vietnamese Fatherland Front and the views on the roles, positions, functions and operation modes of these organizations at the grassroots level in implementing and promoting the people's rights and have a common goal of striving to build a peaceful, independent, unified, democratic, rich and strong Vietnam country with a worthy position in the international arena.

3) The study shows that the entire activities of the Vietnamese Fatherland Front at the current grassroots level in grasping the situation and characteristics of the locality, mobilizing the ethnic minorities, the people, intellectuals, businessmen, overseas Vietnamese, mobilize people of different religions and organize the implementation of the campaign "All people unite to build cultural life in residential areas" in Vietnam today.

\section{References}

[1] Tran Nham (2004). Theoretical thinking with innovation career. Hanoi: National Political Publishing House.

[2] Song Thanh (2013). Ho Chi Minh - A prominent thinker. Hanoi: Political theory Publisher.

[3] Clause 1, Article 1 of the Law on Vietnam Fatherland Front.

[4] Communist Party of Vietnam (2001). Document of the 9th National Party Congress. Hanoi: National Political Publishing House, p. 123. 
[5] Central Propaganda Department - Research Department (2014), Lecture on the work of local people at grassroots level, Hanoi: National Political Publishing House.

[6] Nguyen Viet Thong (2017). The textbook on revolutionary lines of the Communist Party of Vietnam. Hanoi: National political - The truth Publishing House.

[7] Academy of Politics Region II (2012). Lecture Outline of the History of the Communist Party of Vietnam. Hanoi: Politics Administration Publisher.

[8] Ho Chi Minh (2002). Complete Works. Hanoi: National Political Publishing House, p. 605.

[9] Ho Chi Minh National Academy of Politics (2017). Intermediate Curriculum of Political Theory - Administration Operations of the Fatherland Front and mass organizations at grassroots level."Hanoi: Political Theory Publishing House.

[10] Joint Resolution 09/2008 / NQLT-CP-UBTWMTTQVN dated April 17, 2008 guiding the implementation of Articles 11, 14,
16, 22 and 26 of the Ordinance on the implementation of democracy in communes and wards, and town.

[11] Resolution No. 27-NQ / TW of the Seventh Conference of the 10th Central Committee on "Building a contingent of knowledge in the period of accelerating national industrialization and modernization".

[12] Resolution No. 25-NQ / TW dated June 3, 2013 on "Strengthening and renewing the Party's leadership in the mass mobilization work in the new situation" of the 11th Central Committee, at the 7th session.

[13] Project No. 04 / ĐA-MTTW-BTT on the implementation of the campaign "All people unite to build a new style rural area and civilized city" of the Central Committee of the Vietnamese Fatherland Front.

[14] Directive No. 10-CT / TW, dated December 15, 2016 on strengthening the Party's leadership towards the "All people unite to build a new style rural areas, a civilized city" of the Secretariat. 